Volume 13, Nomor 2, November 2021, pp 200-213 Copyright (C) 2017 Jurnal Akuntansi, Program Studi Akuntansi, Fakultas Bisnis, Universitas Kristen Maranatha. ISSN 2085-8698 | e-ISSN 2598-4977. http://journal.maranatha.edu

\title{
Corporate Risk, Cost Shifting, and Tax Avoidance
}

\author{
I Nyoman Agus Wijaya ${ }^{1}$ \\ Program Studi Akuntansi - Fakultas Bisnis - Univ. Kristen Maranatha \\ (Jl. Prof. drg. Surya Sumantri, M.P.H. No.65, Bandung, Jawa Barat) \\ aguswijaya.inyoman@gmail.com \\ Enny Prayogo ${ }^{2}$ \\ Program Studi Akuntansi - Fakultas Bisnis - Univ. Kristen Maranatha \\ (Jl. Prof. drg. Surya Sumantri, M.P.H. No.65, Bandung, Jawa Barat) \\ enny_pray@yahoo.com \\ Rini Handayani ${ }^{3}$ \\ Program Studi Akuntansi - Fakultas Bisnis - Univ. Kristen Maranatha \\ (Jl. Prof. drg. Surya Sumantri, M.P.H. No.65, Bandung, Jawa Barat) \\ rinie 3008@yahoo.com

\section{Ivan Prihartono ${ }^{4}$} \\ Program Studi Akuntansi - Fakultas Bisnis - Univ. Kristen Maranatha \\ (Jl. Prof. drg. Surya Sumantri, M.P.H. No.65, Bandung, Jawa Barat) \\ ivanvhaan@gmail.com
}

\begin{abstract}
This study aims to investigate relationship between corporate risk, cost shifting, and tax avoidance. Using 50 companies of all manufacturing companies listed in Indonesian Stock Exchange, we try to investigate a corporate risk, cost shifting and tax avoidance in annual report audited over long time periods (5 years) sequentially. Then, we test the relationship between corporate risk and cost shifting to tax avoidance that reduced the firm's income tax payments. This study provides evidence that companies with high risk are more likely to do tax avoidance and companies that have a good strategy in allocating their costs are driven by the behavior of minimazing tax payments. We also find that the higher of corporate risk will increase corporate tax payment to Internal Revenue Services.
\end{abstract}

Keywords: Corporate Risk, Cost Shifting, and Tax Avoidance 


\begin{abstract}
Abstrak
Penelitian ini bertujuan untuk menginvestigasi hubungan antara corporate risk, cost shifting, dan tax avoidance. Menggunakan sampel sebanyak 50 perusahaan dari seluruh perusahaan manufaktur yang terdaftar di Bursa Efek Indonesia kami menginvestigasi corporate risk, cost shifting dan tax avoidance pada laporan keuangan auditan yang terbit di Bursa Efek Indonesia selama 5 tahun berturut-turut. Kemudian kami menguji hubungan corporate risk dan cost shifting terhadap tax avoidance yang dilakukan oleh perusahaan untuk mengurangi jumlah pajak yang dibayarkan kepada negara. Penelitian ini memberikan bukti bahwa perusahaan dengan risiko yang tinggi lebih cenderung melakukan tax avoidance dan perusahaan yang memiliki strategi yang baik dalam mengalokasikan biayanya didorong oleh perilaku meminimalkan pembayaran pajak. Kami juga menemukan semakin tinggi resiko dari suatu perusahaan maka akan meningkatkan pembayaran pajak perusahaan kepada layanan pendapatan internal dari suatu negara.
\end{abstract}

\title{
Kata Kunci: Corporate Risk, Cost Shifting, dan Tax Avoidance
}

\section{Pendahuluan}

Setiap perusahaan di dunia memiliki perencanaan pajak dimana perencanaan ini tidak terpisahkan dari strategi yang diaplikasikan oleh manajemen. Baik perusahaan besar maupun perusahaan kecil memiliki strategi yang berbeda-beda dalam menerapkan strategi perencanaan pajaknya. Salah satu strategi perencanaan pajak yang paling banyak digunakan oleh perusahaan adalah penghindaran pajak (tax avoidance).

Manajer perusahaan banyak menerapkan berbagai macam strategi yang memungkinkan untuk dapat mengurangi jumlah pembayaran pajak yang harus dibayarkan oleh perusahaan yang dikelolanya. Hal tersebut didorong oleh motivasi untuk mendapatkan insentif atas kemampuan manajer perusahaan dalam mengurangi jumlah pembayaran pajak perusahaannya. (Brown, Drake, and Martin 2016; Rego and Wilson 2012; Boivie et al 2012; Higgins, Omer and Phillips 2012; and Robinson, Xue, and Zhang 2012). Penerapan kebijakan perpajakan dalam suatu perusahaan telah mendapat perhatian penuh dari para peneliti, penelitian sebelumnya banyak yang menggunakan laba sebelum pajak dan laba kena pajak untuk menentukan penerapan kebijakan perpajakan (tax avoidance) yang diterapkan oleh perusahaan (Dyreng, Hanlon and Maydew 2014). Banyak penelitian sebelumnya melaporkan penemuan empirisnya yang memfokuskan pada laba sebelum pajak untuk menentukan jumlah penghindaran pajak yang diterapkan oleh CEO perusahaan (Hanlon, Laplante and Shevlin 2005; Guenther, Matsunaga, and Williams 2017; McGuire, Neuman and Omer 2013; Dyreng, Hanlon and Maydew 2014; and Dhaliwal, Grace, Pincus, and Steele 2017), namun sedikit sekali penelitian yang memfokuskan perhatian pada risiko perusahaan terhadap penghindaran pajak oleh manajer.

Penelitian ini memfokuskan perhatian pada risiko perusahaan (corporate risk) yang mempengaruhi tax avoidance. Tujuan kami melakukan penelitian ini adalah menyediakan pemahaman yang mendalam mengenai latar belakang perusahaan yang memiliki risiko yang tinggi yang dihadapi baik risiko itu berupa risiko kegagalan pembayaran pokok hutang beserta bunganya maupun kegagalan perusahaan mendapatkan profit selama menjalankan bisnisnya.

Risiko yang dihadapi perusahaan akan mendorong manajer melakukan 
tindakan-tindakan yang tidak melanggar peraturan pajak untuk dapat mengurangi jumlah pajak yang akan dibayarkan dimasa yang akan datang. Selain itu, peneliti akuntansi keuangan dan perpajakan serta para analis keuangan akan mendapatkan pemahaman dan informasi yang mendalam mengenai pengukuran penghindaran pajak selama periode jangka panjang yang dilakukan perusahaan yang mampu menguntungkan perusahaan dengan memanfaatkan berbagai macam celah yang ada didalam peraturan perpajakan dan melihat hubungannya antara risiko yang dihadapi perusahaan dengan motivasi penghindaran pajak yang dilakukan oleh manajemen perusahaan.

Penelitian yang kami lakukan berbeda dengan penelitian yang dilakukan oleh Dhaliwal, Grace, Pincus, and Steele (2015) yang juga melakukan penelitian mengenai hubungan antara laba kena pajak dan risiko perusahaan (firm risk) dan penelitian yang dilakukan oleh Langenmayr and Lester (2018) yang meneliti hubungan perpajakan dengan perusahaan pengambil risiko (corporate risk-taking). Penelitian ini menginvestigasi hubungan antara risiko perusahaan (corporate risk), cost shifting dan tax avoidance. Untuk menginvestigasi hubungan antara risiko perusahaan (corporate risk) cost shifting dan tax avoidance, kami pertama-tama melakukan pengukuran atas tax avoidance menggunakan rumus yang dikembangkan oleh Dyreng, Hanlon dan Maydew (2008) yang menggunakan Cash Effective Tax Rate (Cash ETR). Melalui rumus ini, Dyreng, Hanlon dan Maydew (2008) menjumlahkan total kas pajak yang dibayarkan oleh perusahaan selama periode jangka panjang dan membaginya dengan jumlah laba sebelum pajak selama periode jangka panjang. Pengukuran Effective Tax Rate (ETR) yang menggunakan periode jangka pajang akan memberikan pengukuran yang lebih baik dan tepat serta mampu menghindarkan pengaruh aktivitas akrual manajemen dibandingkan jika menggunakan perhitungan Effective Tax Rate (ETR) setahun karena periode jangka panjang mampu menangkap pembalikkan akrual yang diterapkan oleh manajemen (Dyreng et al, 2008). Dyreng et al (2008) menyadari bahwa pajak tunai yang dibayarkan selama jangka waktu pendek (satu tahun) merupakan alat ukur penghindaran pajak yang kurang sempurna karena periode tersebut memasukkan pembayaran kepada (restitusi pajak dari) Kantor Pelayanan Pajak sebagai suatu otoritas pajak setelah menyelesaikan perselisihan pajak yang timbul pada tahun lalu.

Pertama, kami ingin melihat apakah risiko yang dihadapi perusahaan mampu mendorong manajamen untuk melakukan penghindaran pajak. Pengukuran risiko perusahaan dalam penelitian ini mengacu kepada buku referensi mengenai analisis laporan keuangan (seperti analisis laporan keuangan, Subramanyam 2013). Penelitian ini ingin menginvestigasi apakah risiko yang dihadapi oleh perusahaan (seperti risiko kegagalan pembayaran hutang jangka panjang mampu menjadi penentu perusahaan melakukan tax avoidance. Seperti yang kita ketahui bahwa perusahaan yang sedang menghadapi risiko kegagalan pembayaran pokok dan bunga atas hutang jangka panjangnya akan membuat perusahaan menghadapi ketidakpastian dalam pembayaran hutang jangka panjangnya (Subramanyam, 2013:138). Hal tersebut membuat manajemen mengambil langkah untuk mengamankan aliran kasnya atau berupaya melakukan efisiensi pengeluaran kas. Bentuk dari efisiensi pengeluaran kas adalah dengan menerapkan tindakan-tindakan dari manajemen yang mana memanfaatkan celah dalam peraturan perpajakan sehingga perusahaan dapat mengurangi jumlah pajak penghasilan yang dibayarkan kepada Negara (Dyreng, Hanlon and Maydew 2008).

Kedua kami melakukan investigasi atas cost shifting yang dilakukan manajemen perusahaan dalam rangka untuk meminimalkan jumlah pajak yang 
dibayarkan kepada Negara. Manajemen perusahaan pada dasarnya memiliki kebebasan untuk mengatur transaksi perusahaannya agar dapat meminimalkan jumlah pajak yang dibayarkan kepada Negara dan salah satunya adalah melalui tindakan cost shifting (Hall and Lusch 2018). Dengan melakukan cost shifting maka biaya pada laporan laba-rugi perusahaan akan meningkat dan berdampak pada penurunan laba sebelum pajak perusahaan yang pada akhirnya akan meminimalkan jumlah pajak yang dibayarkan kepada Negara.

Hasil investigasi terhadap hubungan antara risiko perusahaan, peningkatan biaya dan penghindaran pajak ini sangat penting agar para pembaca dapat melihat faktor penentu dari penghindaran pajak yang dilakukan oleh manajemen. Penelitian ini dapat memberikan kontribusi bagi penelitian selanjutnya sebagai bahan dalam melakukan riset lanjutan sehubungan dengan penelitian terhadap penghindaran pajak. Penelitian ini juga dapat memberikan kontribusi bagi petugas pajak (KPP) untuk dapat lebih memperhatikan faktor yang menentukan perusahaan melakukan penghindaran pajak sehingga dapat membuat suatu regulasi yang dapat menutupi celah perusahaan melakukan penghindaran pajak yang melanggar peraturan perpajakan.

\section{Kerangka Teoritis dan Hipotesis}

\section{Agency Theory}

Teori keagenan adalah pengembangan dari suatu teori yang mempelajari suatu desain kontrak dimana para agen bekerja atau bertugas atas nama principal ketika keinginan atau tujuan agen bertolak belakang maka akan terjadi suatu konflik.

Konflik keagenan yang ditimbulkan oleh tindakan perataan laba dipicu dari adanya pemisahan peran atau perbedaan kepentingan antara principal dengan agen. Secara actual teori keagenan memiliki karakteristik kooperatif dan non kooperatif.
Dalam konsep teori agensi, manajemen sebagai agen semestinya mengutamakan kepentingan pemegang saham, akan tetapi tidak tertutup kemungkinan manajemen hanya mementingkan kepentingannya sendiri untuk memaksimalkan utililitas. Manajemen dapat melakukan tindakantindakan yang tidak menguntungkan perusahaan secara keseluruhan yang dalam jangka panjang bisa merugikan kepentingan perusahaan. Bahkan untuk mencapai kepentingannya sendiri, manajemen dapat bertindak menggunakan akuntansi sebagai alat untuk melakukan rekayasa. Perbedaan kepentingan antara prinsipal dan agen inilah disebut dengan agency problem yang salah satunya disebabkan oleh adanya asimetri informasi. Pertentangan dan tarik menarik kepentingan antara prinsipal dan agen dapat menimbulkan permasalahan yang dalam Agency Theory dikenal sebagai Asymmetric Information (AI) yaitu informasi yang tidak seimbang yang disebabkan karena adanya distribusi informasi yang tidak sama antara prinsipal dan agen. Ketergantungan pihak eksternal pada angka akuntansi, kecenderungan manajer untuk mencari keuntungan sendiri dan tingkat $A I$ yang tinggi, menyebabkan keinginan besar bagi manajer untuk memanipulasi kerja yang dilaporkan untuk kepentingan diri sendiri. (Scott, 2003:305)

Menurut Eisenhard (1989), teori keagenan dilandasi oleh 3 buah asumsi yaitu: 1. Asumsi tentang sifat manusia menekankan bahwa manusia memiliki sifat untuk mementingkan diri sendiri (self interest), memiliki keterbatasan rasionalitas (bounded rationality), dan tidak menyukai resiko (risk aversion).

2. Asumsi tentang keorganisasian - adalah adanya konflik antar anggota organisasi, efisiensi sebagai kriteria produktivitas, dan adanya Asymmetric Information ( $A I)$ antara prinsipal dan agen.

3. Asumsi tentang informasi - Asumsi tentang informasi adalah bahwa informasi dipandang sebagai barang komoditi yang bisa diperjualbelikan. 


\section{Tax Planning}

Tax planning adalah upaya wajib pajak untuk mengoptimalkan pajak pada jumlah minimum yang dimungkinkan dalam peraturan perundangan-undangan perpajakan sehingga tidak menimbulkan dispute antara wajib pajak dengan otoritas pajak. Perusahaan menerapkan tax planning agar beban pajak yang dibayarkan tidak terlalu membebankan profit yang diperoleh perusahaan.

\begin{tabular}{lccr}
\multicolumn{2}{c}{ Penerapan tax planning yang } \\
dilakukan oleh manajemen dalam \\
perusahaan
\end{tabular} memungkinkan pembaca laporan keuangan melihat kinerja manajemen yang lebih baik yang direfleksikan dalam laba bersih perusahaan. Penerapan strategi tersebut juga menghindari baik manajemen maupun investor dari dispute yang muncul dengan otoritas pajak.

\section{Tax Avoidance}

Tax avoidance merupakan salah satu jenis dari tax planning. Tax avoidance didefinisikan sebagai tindakan-tindakan yang dilakukan oleh manajemen yang tidak melanggar peraturan perpajakan dengan tujuan untuk meminimalkan jumlah pajak yang dibayarkan oleh perusahaan kepada Negara (Dyreng, Hanlon and Maydew 2008). Terdapat beberapa cara tindakan tax avoidance yang dilakukan oleh manajemen perusahaan yakni dengan cara meningkatkan biaya (cost shifting) sepanjang diizinkan oleh peraturan perundang-undangan perpajakan dengan tujuan meminimalkan jumlah pajak yang dibayarkan oleh perusahaan kepada otoritas pajak. Perusahaan juga dapat meminimalkan jumlah pajak yang dibayarkan melalui diversifikasi perusahaan sehingga memungkinkan pemilik perusahaan membagi jumlah laba sebelum pajak yang semula besar menjadi lebih kecil. Diversifikasi perusahaan dilakukan dengan tanpa mengaitkan operasional antar perusahaan yang terdiversifikasi tersebut. Perusahaan juga dapat mendirikan anak 204 perusahaan pada daerah atau Negara lain dengan tujuan untuk membagi jumlah laba yang didapatkan perusahaan sehingga akan meminimalkan jumlah pajak yang dibayarkan perusahaan kepada Negara tempat perusahaan beroperasi.

\section{Risiko Perusahaan (Corporate Risk)}

Suatu perusahaan akan menghadapi risiko kepailitan jika perusahaan mengalami kegagalan pembayaran pokok dan hutang bunga untuk kewajiban jangka panjangnya. Tingkat kegagalan yang tinggi atas pembayaran pokok dan hutang bunga untuk kewajiban jangka panjang akan membuat perusahaan mengalami kebangkrutan dan memaksa perusahaan untuk menjual asetnya dalam rangka memenuhi kewajiban jangka panjangnya tersebut. Perusahaan menjual asetnya dalam rangka untuk memenuhi kebutuhan kas perusahaan untuk melunasi kewajiban jangka panjangnya serta kewajiban jangka pendeknya termasuk pembayaran pajak perusahaan yang terhutang. Sebaliknya, perusahaan dengan tingkat kegagalan pembayaran pokok dan hutang bunga atas kewajiban jangka penjangnya akan meminimalkan risiko perusahaan mengalami kebangkrutan. Risiko kegagalan pembayaran pokok dan hutang bunga atas kewajiban jangka panjangnya juga dapat menjadi indikator kesehatan keuangan suatu perusahaan.

\section{Cost Shifting}

Perusahaan memiliki kebebasan dalam menentukan transaksinya dalam rangka untuk memenuhi tujuan manajemen. Contohnya perusahaan memiliki kebebasan dalam mengatur transaksinya sehubungan dengan jumlah pajak yang dibayarkan oleh perusahaan kepada Negara. Biaya-biaya yang dikeluarkan perusahaan sehubungan dengan peningkatan aset, namun karena jumlahnya kecil perusahaan mencatatnya sebagai biaya. Dalam hal ini perusahaan dapat meminimalkan jumlah pajak dengan signifikan untuk dibayarkan kepada Negara. 


\section{Risiko Perusahaan (Corporate Risk), Cost Shifting dan Tax Avoidance}

Guenther, Matsunaga, and Williams (2013) telah melakukan penelitian yang berjudul tax avoidance, tax aggressiveness, task risk and firm risk. Guenther, Matsunaga, and Williams (2013) membedakan konsep tax avoidance, tax aggressiveness, dan tax risk serta menguji hubungan antara ketiga konsep tersebut terhadap volatilitas pengembalian saham dimasa yang akan datang. Hasil dari penelitian tersebut menjelaskan mengenai tax avoidance. Tax avoidance merepresentasikan kemampuan perusahaan untuk mengurangi pembayaran pajaknya dan diukur melalui cash effective tax rate. Sedangkan tax aggressiveness merepresentasikan sejauh mana perusahaan mengambil posisi pajak yang tidak mungkin didukung oleh otoritas pajak dan tax aggressiveness diukur menggunakan cadangan manfaat pajak yang tidak diakui yang diukur besarnya melalui perhitungan total aset yang tertinggal. Penelitian tersebut juga menjelaskan bahwa risiko pajak ( $\operatorname{tax}$ risk) merepresentasikan kemampuan perusahaan untuk mempertahankan posisinya sepanjang waktu, tax risk ini diukur melalui standar deviasi dari cash effective tax rates tahunan. Hasil dari penelitian tersebut juga menemukan hubungan positif secara signifikan antara risiko pajak dan risiko perusahaan (firm risk), tetapi tidak menemukan bukti hubungan yang signifikan baik antara tax avoidance dan risiko perusahaan. Aktivitas yang mengurangi pembayaran pajak perusahaan akan meningkatkan risiko perusahaan.

Penelitian mengenai laba kena pajak (taxable income) dan risiko perusahaan telah dilakukan oleh Dhaliwal, Lee, Pincus dan Steele (2015), Rego and Wilson 2012; Boivie et al 2012. Dhaliwal, Lee, Pincus dan Steele (2015) menguji laba kena pajak berdasarkan pada pengukuran variasi crosssectional dalam prediktabilitas dan variabilitas laba sebelum pajak dimasa yang akan datang. Penelitian tersebut juga menginvestigasi hubungan antara pengukuran tersebut dengan variasi dalam pengukuran risiko perusahaan berdasarkan pasar. Penelitian tersebut menemukan dampak informasi akuntansi terhadap penilaian investor atas risiko perusahaan serta peningkatan pemahaman atas luas dan sifat dari informasi yang terkandung dalam laba kena pajak.

Dyreng, Hanlon dan Maydew (2008) mengembangkan pengukuran jangka panjang mengenai tax avoidance perusahaan yang berdasarkan pada kemampuan pembayaran kas dalam jumlah yang kecil untuk pajak atas laba sebelum pajak selama periode jangka panjang. Penelitian tersebut menggunakan 2.077 perusahaan sebagai sampel dan berhasil menemukan bahwa persistensi dari tingkat cash effective tax tahunan yang rendah dan kemampuan nyata dari perusahaan untuk menghindari pajak dalam periode jangka panjang dapat didorong oleh tindakan manajemen untuk menghindari pajak atau dilakukan pada kelompok perusahaan tertentu.

Scholes et al. (1990) melakukan penelitian mengenai pengaruh pajak terhadap keputusan manajerial dalam perbankan. Mereka menemukan bahwa perbankan menyesuaikan kepemilikan atas obligasi kota (municipal bonds) sebagai tanggapan terhadap usulan dan perubahan aktual dalam hukum perpajakan untuk obligasi kota (municipal bonds) yang dimiliki oleh perbankan. Perbankan akan lebih mampu membayar pajak untuk yang berhubungan dengan realisasi keuntungan dari sekuritas. Beatty, Chamberlain, dan Magliolo (1995) menemukan bahwa biaya pinjaman (loan charge-offs), provisi kerugian pinjaman (loan loss provisions), dan keputusan untuk menerbitkan sekuritas ditentukan secara bersama-sama (berpengaruh secara bersama-sama) terhadap pemenuhan tujuan modal dan laba untuk periode berjalan. Penelitian ini mencoba untuk menguji perusahaan yang sedang menghadapi risiko (seperti kegagalan pembayaran pokok dan bunga 
atas hutang jangka panjang) akan lebih cenderung melakukan tax avoidance dibandingkan dengan perusahaan yang tidak terdapat masalah atas hutang jangka panjangnya. Perusahaan yang sedang menghadapi risiko kegagalan pembayaran pokok dan bunga atas hutang jangka panjangnya akan cenderung menghemat kasnya (termasuk melakukan tax avoidance) dalam rangka memenuhi kecukupan kasnya untuk dapat membayar pokok dan bunga atas kewajiban jangka panjangnya. Hal tersebut menimbulkan hipotesis untuk diuji, yakni:

H1: corporate risk memiliki pengaruh secara positif terhadap peningkatan tax avoidance

Hall dan Lusch (2018) melakukan penelitian mengenai strategic cost shifting and state tax minimation. Mereka memprediksi dan menemukan bahwa perusahaan induk perbankan di negara yang berbeda dengan anak perusahaan secara strategis mengalokasikan biaya diantara anak perusahaan perbankannya untuk meminimalkan pembayaran pajak (Hanlon, Laplante and Shevlin 2005; Hanlon and Maydew 2014).

Selain itu, penelitian tersebut memperoleh bukti bahwa anak perusahaan perbankan dari induk perbankan yang berbeda Negara yang memiliki pajak Negara yang tinggi cenderung memiliki biaya yang tinggi dibandingkan dengan perbankan pada suatu Negara yang tidak memiliki perusahaan induk dalam Negara yang memiliki pajak yang sama tingginya. Menurut strategi cost shifting, pajak akan menjadi rendah melalui penempatan biayabiaya tertentu (seperti biaya pegawai, gaji staf administrasi/back-office) dalam yuridiksi pajak yang tinggi dan memilih dasar yang layak untuk mengalokasikan overhead cost yang dihasilkan dalam jumlah yang tinggi ke yuridiksi yang memiliki pajak yang tinggi (sehingga mengurangi laba kena pajak dalam yuridiksi yang memiliki pajak yang tinggi) dan mengalokasikan overhead cost yang berjumlah kecil ke yuridiksi yang memiliki pajak yang rendah (sehingga menghasilkan peningkatan dalam laba kena pajak dalam yuridiksi yang memiliki pajak yang rendah). Hal tersebut memunculkan hipotesis untuk diuji, yakni:

H2: cost shifting memiliki pengaruh secara positif terhadap peningkatan tax avoidance

\section{Metode Penelitian}

\section{Jenis Penelitian}

Berdasarkan data yang dikumpulkan selama penelitian mengenai fakta dan sifat dari obyek yang diteliti secara sistematis dengan menggabungkan hubungan antar variabel yang terlibat didalamnya dan diukur secara kuantitas atau jumlahnya, penelitian yang kami gunakan merupakan penelitian dengan pendekatan kuantitatif.

\section{Populasi dan Sampel Penelitian}

Populasi dalam penelitian ini adalah seluruh perusahaan manufaktur yang terdaftar di Bursa Efek Indonesia (BEI) pada tahun 2014 $-2017$.

Tabel 1

Populasi Perusahaan Manufaktur di BEI Tahun 2014 - 2017

\begin{tabular}{|c|c|c|}
\hline No. & Kriteria & Jumlah \\
\hline 1. & Industri Dasar \& Kimia & 65 \\
\hline 2. & Aneka Industri & 44 \\
\hline 3. & Industri Barang Konsumsi & 39 \\
\hline & Jumlah & 148 \\
\hline
\end{tabular}

Sumber: www.idx.co.id

Teknik sampel yang digunakan adalah dengan purposive sampling, yaitu metode pemilihan sampel dengan kriteria tertentu. Kriteria yang ditetapkan dalam pengambilan sampel pada penelitian ini ditentukan sebagai berikut:

1) Perusahaan manufaktur yang terdaftar di Bursa Efek Indonesia (BEI) tahun 2014-2017.

2) Perusahaan yang konsisten mempublikasikan laporan tahunannya 
secara berturut-turut dari tahun 20142017.

3) Perusahaan yang mengungkapkan laporan tahunannya pada akhir Desember tahun 2014-2017.

4) Perusahaan yang mengalami laba pada tahun 2014-2017.

Berdasarkan proses pemilihan sampel sesuai dengan kriteria pengambilan sampel, maka diperoleh 50 perusahaan yang menjadi sampel dalam penelitian ini. Penelitian ini menggunakan perusahaan manufaktur sebagai populasi dan sampel penelitian karena perusahaan manufaktur memiliki fleksibilitas yang lebih tinggi untuk dapat diatur oleh manajemen agar dapat mencapai tujuannya yakni penghindaran pajak.

\section{Objek Penelitian}

Objek penelitian pada dasarnya merupakan variabel atau apa yang menjadi titik perhatian suatu penelitian untuk mendapatkan jawaban ataupun solusi dari permasalahan yang terjadi.

Objek dari penelitian ini adalah laporan keuangan tahunan perusahaan manufaktur yang terdaftar di Bursa Efek Indonesia selama tahun 2014-2017.

\section{Jenis dan Sumber Data Penelitian}

Data sekunder merupakan data yang telah diolah atau data yang menunjang data primer dimana dapat berupa hasil tulisan, grafik, foto atau hasil yang lainnya. Data sekunder yang diperoleh oleh peneliti yaitu laporan keuangan perusahaan manufaktur yang listing di bursa efek. Data ini merupakan data yang berhubungan secara langsung dengan sumber penelitian.

Sumber data yang dilakukan dalam penelitian ini data sekunder yang diperoleh langsung dari bursa efek Indonesia melalui situs resminya yaitu www.idx.co.id.

\section{Metode Penelitian}

Dalam melaksanakan penelitian, metode yang digunakan dalam penelitian ini adalah metode hubungan kausal, dimana metode hubungan kausal menurut Sugiyono
(2013:37) adalah hubungan yang bersifat sebab akibat. Dalam penelitian ini terdapat dua jenis variabel yaitu Corporate Risk dan Cost Shifting sebagai varibel independen dan variabel Tax Avoidance sebagai variabel dependen.

\section{Operasionalisasi Variabel Penelitian}

Sesuai dengan judul penelitian mengenai corporate risk, cost shifting dan tax avoidance, maka operasionalisasi variabel penelitian dapat dilihat pada tabel di bawah ini:

\section{Tabel 2}

\section{Operasional Variabel}

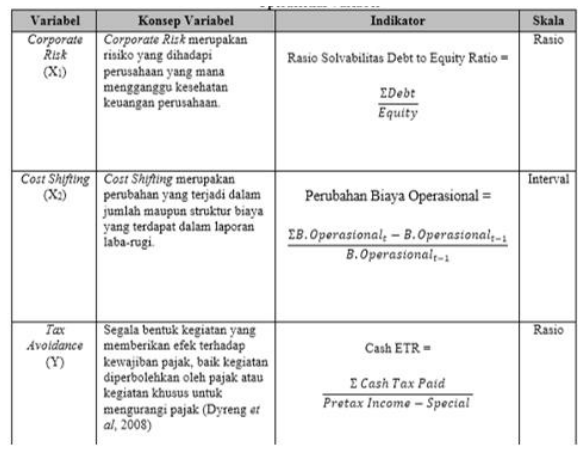

Metode Pengujian Data Penelitian

Kami melakukan analisa terhadap data yang telah diuraikan dengan menggunakan empat uji asumsi klasik. Menurut Ghozali (2011) uji asumsi klasik digunakan untuk mendapatkan model regresi yang baik, terbebas dari penyimpangan data yang terdiri dari normalitas, multikolinearitas, autokorelasi dan heteroskedastisitas. Cara yang digunakan untuk menguji penyimpangan-penyimpangan dalam asumsi kaslik adalah sebagai berikut:

\section{Uji Normalitas}

Menurut Ghozali (2011) uji normalitas bertujuan untuk menguji apakah di dalam sebuah model regresi, variabel pengganggu atau residual memiliki distribusi normal atau tidak. Seperti yang diketahui bahwa uji t dan uji $\mathrm{F}$ mengasumsikan bahwa nilai residual mengikuti distribusi normal. Jika asumsi ini dilanggar maka uji statistik dianggap tidak 
valid. Model regresi dikatakan baik dan layak digunakan adalah apabila memiliki distribusi normal atau mendekati normal. Menurut Husein (2011) dasar pengambilan keputusan bisa dilakukan berdasarkan nilai probabilitas (Asymtotic Significance), yaitu dengan kriteria:

a) Jika probabilitas $>0,05$ maka distribusi dari populasi adalah normal.

b) Jika probabilitas < 0,05 maka populasi tidak berdistribusi secara normal.

\section{Uji Multikolinearitas}

Menurut Ghozali (2011:62) Uji Multikolinearitas bertujuan untuk menguji apakah dalam model regresi ditemukan adanya korelasi antar variabel independen. Asumsi multikolinearitas menyatakan bahwa variabel bebas dalam regresi berganda harus terbebas dari gejala multikolinearitas. Gejala multikolinearitas adalah gejala korelasi antar variabel independen. Deteksi ada tidaknya multikolinearitas dilakukan dengan melihat nilai VIF (Variable Inflation Factor) dan nilai tolerance. Model regresi dikatakan bebas dari multikolinearitas apabila nilai VIF < 10, dan tolerance > 0,1 (10\%). Sebagai dasar acuannya dapat disimpulkan:

a) Jika nilai tolerance $>10 \%$ dan nilai VIF $<10$, maka dapat disimpulkan bahwa tidak ada multikolinearitas antar variabel independen dalam model regresi.

b) Jika nilai tolerance $<10 \%$ dan nilai VIF > 10, maka dapat disimpulkan bahwa ada multikolinearitas antar variabel independen dalam model regresi.

\section{Uji Heteroskedastisitas}

Menurut Ghozali (2011) uji heteroskedastisitas bertujuan untuk menguji apakah dalam model regresi terjadi ketidaksamaan antar variance dari nilai residual satu pengamatan ke pengamatan yang lain. Jika variance dari residual satu pengamatan ke pengamatan yang lain tetap, maka disebut homoskedastisitas dan jika 208 berbeda maka dikatakan terjadi heteroskedastisitas. Model regresi yang baik adalah apabila dalam suatu pengamatan antar variabel terjadi homoskedastisitas atau tidak tejadi heteroskedastisitas. Cara untuk mengetahui ada tidaknya heteroskedastisitas adalah dengan pengujian menggunakan metode pengujian glesjer. Heteroskedastisitas terjadi bila nilai sig > alpha, dan sebaliknya jika sig < alpha, maka terjadi homoskedastisitas.

\section{Uji Autokorelasi}

Menurut Husein (2011:182) uji asumsi klasik autokorelasi adalah pengujian yang dilakukan untuk mengetahui apakah dalam sebuah model regresi linier terdapat hubungan yang kuat baik positif maupun negatif antar data yang ada pada variabelvariabel penelitian. Untuk data dalam bentuk cross section, harus dilakukan pengujian apakah terdapat hubungan yang kuat di antara data pertama dan kedua, data kedua dengan ke tiga dan seterusnya. Jika terdapat hubungan yang kuat berarti telah terjadi autokorelasi. Hal ini akan menyebabkan informasi yang diberikan menjadi menyesatkan. Oleh karena itu, perlu tindakan agar tidak terjadi autokorelasi. Pada pengujian autokorelasi digunakan metode pengujian Runs Test. Kriteria yang digunakan dalam uji Runs Test adalah apabila nilai asymp. Sig. > dari 5\%, maka tidak terjadi gejala autokorelasi dan sebaliknya jika asymp. Sig. < dari $5 \%$, maka terjadi gejala autokorelasi dalam model regresi.

\section{Metode Analisis Data Penelitian}

Dalam penelitian ini, analisis regresi linier berganda digunakan untuk membuktikan sejauh mana hubungan Corporate Risk, Cost Shifting dan Tax Avoidance.

Menurut Sugiyono (2013:261) bentuk persamaan dari regresi linier berganda ini adalah sebagai berikut: 


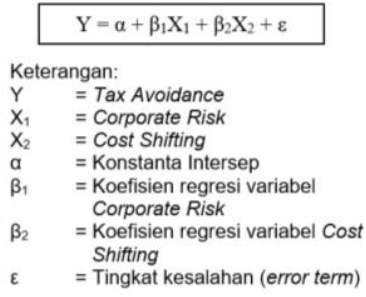

Uji statistik $t$ (parsial) digunakan untuk menguji apakah dalam model regesi terdapat pengaruh secara signifikan masing-masing variabel independen $(\mathrm{X})$ dengan variabel dependen $(\mathrm{Y})$. Hipotesis nol $\left(\mathrm{H}_{0}\right)$ tidak terdapat pengaruh yang signifikan dan Hipotesis alternatif $\left(\mathrm{H}_{1}\right)$ menunjukkan adanya pengaruh antara variabel independen dan variabel dependen.

\section{Hasil Penelitian dan Pembahasan}

\section{Hasil Penelitian Deskriptif}

Dalam penelitian ini, sampel yang diambil untuk dilakukan penelitian adalah 50 perusahaan manufaktur yang terdaftar di Bursa Efek Indonesia (BEI) yang memenuhi kriteria dan pertimbangan yang dilakukan oleh peneliti. Berdasarkan hasil pengujian berikut adalah statistik deskriptif masingmasing variabel untuk masing-masing hipotesis:

Tabel 3

\begin{tabular}{|l|r|r|r|r|r|}
\hline \multicolumn{6}{|c|}{ Deskripsi Variabel Penelitian } \\
\hline & \multicolumn{1}{|c|}{$\mathrm{N}$} & \multicolumn{1}{|c|}{ Minimum } & \multicolumn{1}{c|}{ Maximum } & \multicolumn{1}{c|}{ Mean } & \multicolumn{1}{|c|}{ Sid. Deviation } \\
\hline TAX_AVOIDANCE & 140 & 0,0800 & 3,0300 & 0,790000 & 0,6308222 \\
\hline CORPORATE_RISK & 140 & $-1,0000$ & 3,7718 & 0,159190 & 0,4296284 \\
\hline COST_SHIFIING & 140 & 0,0300 & 0,4700 & 0,253643 & 0,0613659 \\
\hline
\end{tabular}

(Sumber: Data sekunder diolah)

Berdasarkan pengamatan yang dilakukan diperoleh deskripsi data penelitian yang dijelaskan sebagai berikut:

1. Jumlah sampel dari 50 perusahaan yang memenuhi kriteria, hanya 35 perusahaan masing-masing terdiri dari 4 tahun (2014 - 2017) yang dapat digunakan untuk pengujian hipotesis.
2. Nilai minimum Tax Avoidance dari 35 perusahaan manufaktur yang terdaftar di BEI adalah 0.0800 dengan nilai maximum nya adalah 3.0300 dan ratarata nilai tax avoidance 35 perusahaan manufaktur adalah 0,790000 dengan standar deviasi 0,6308222

3. Nilai minimum Corporate Risk dari 35 perusahaan manufaktur yang terdaftar di BEI adalah - 1.000 dengan nilai maximum nya adalah 3.7718 dan rata-rata nilai Corporate Risk 35 perusahaan manufaktur adalah 0,159190 dengan standar deviasi 0,4296284 .

4. Nilai minimum Cost Shifting dari 35 perusahaan manufaktur yang terdaftar di BEI adalah 0,0300 dengan nilai maximum nya adalah 0,4700 dan ratarata nilai Corporate Risk 35 perusahaan manufaktur adalah 0,253643 dengan standar deviasi 0,0613659.

\section{Hasil Uji Normalitas}

Uji normalitas One Sample Kolmogorov Smirnov bertujuan untuk menguji apakah dalam model regresi, variabel independen dan dependen terdistribusi normal atau tidak. Untuk melakukan uji normalitas data, alat uji yang digunakan dalam penelitian ini adalah One Sample Kolmogorov Smirnov dan hasilnya diperoleh sebagai berikut:

\section{Tabel 4}

Normalitas Data

\begin{tabular}{|c|c|}
\hline \multicolumn{2}{|c|}{ One-Sample Kolmogorov-Smirnov Test } \\
\hline & Unstandardized Residual \\
\hline Assymp. Sig (2-tailed) & 0.567 \\
\hline \multicolumn{2}{|c|}{ (Sumber: Data sekunder diolah) }
\end{tabular}

Berdasarkan tabel 4.2 diatas, nilai sig sebesar $0.567>0.05$ maka dapat disimpulkan bahwa variabel dependen dan independen dalam penelitian ini terdistribusi normal dan layak untuk digunakan dalam pengujian hipotesis menggunakan uji regresi. 


\section{Hasil Uji Multikolinearitas}

Menurut Ghozali (2011) Uji multikolinearitas bertujuan untuk menguji apakah dalam model regresi ditemukan adanya korelasi antar variabel independen. Pengujian asumsi klasik multikolinearitas menyatakan bahwa seluruh variabel independen harus terbebas dari gejala multikolinearitas. Gejala multikolinearitas adalah gejala korelasi antar variabel bebas. Deteksi ada tidaknya multikolinearitas dilakukan dengan melihat nilai VIF (Variable Inflation Factor) dan tolerance. Dari hasil SPSS diperoleh hasil sebagai berikut:

Tabel 5

Hasil Uji Multikolineritas

\begin{tabular}{|l|c|c|}
\hline \multicolumn{3}{|c|}{ Collinearity Statistic } \\
\hline & Tolerance & VIF \\
\hline CORPORATE_RISK & 0.897 & 1.000 \\
\hline COST_SHIFTING & 0.897 & 1.000 \\
\hline
\end{tabular}

(Sumber: Data sekunder diolah)

Berdasarkan tabel 4.3 diatas, nilai Tolerance Corporate Risk dan Cost Shifting masingmasing sebesar $0.897>0.1$ sedangkan nilai VIF Corporate Risk dan Cost Shifting masing-masing sebesar $1.000<10$, hal ini menunjukkan bahwa data terbebas dari multikolinearitas dan layak untuk digunakan dalam pengujian hipotesis menggunakan uji regresi.

\section{Hasil Uji Heteroskedastisitas}

Pengujian asumsi klasik lain yang harus tepenuhi dalam analisa regresi berganda adalah uji heteroskedastisitas. Tujuan dari pengujian asumsi klasik heteroskedastisitas adalah untuk menguji apakah di dalam model regresi terjadi ketidaksamaan varians dari variabel - variabel independen dan dependen dari satu pengamatan ke pengamatan lain. Pengujian heteroskedastisitas dalam penelitian ini menggunakan metode Glejser dan diperoleh hasil sebagai berikut:
Tabel 6 Hasil Uji Heteroskedastisitas

\begin{tabular}{|c|c|}
\hline \multicolumn{2}{|c|}{ Coefficients } \\
\hline Model & Sig. \\
\hline Constant & 0.000 \\
\hline CORPORATE_RISK & 0.342 \\
\hline COST_SHIFTING & 0.655 \\
\hline
\end{tabular}

(Sumber: Data sekunder diolah)

Berdasarkan tabel 4.4 diatas, terlihat bahwa nilai sig. dari variabel Corporate Risk sebesar $0.342>\alpha(0,05)$ dan nilai sig Cost Shifting sebesar $0.655>\alpha(0,05)$ maka semua variabel dikatakan terbebas dari heteroskedastisitas dan hal ini berarti terlihat bahwa penyebaran data dari waktu ke waktu selalu konsisten.

\section{Hasil Uji Autokorelasi}

Pengujian asumsi klasik lainnya yang harus terpenuhi untuk data Cross Section adalah Uji autokorelasi dimana pengujian ini dilakukan untuk mengetahui apakah dalam sebuah model regresi linier terdapat korelasi antara kesalahan pengganggu pada periode $t$ dengan kesalahan pada periode $\mathrm{t}-1$. Salah satu cara yang digunakan untuk mendeteksi terjadi nya autokorelasi dalam model regresi adalah dengan menggunakan uji run test. Dari hasil SPSS diperoleh data sebagai berikut:

Tabel 7

Hasil Uji Autokorelasi

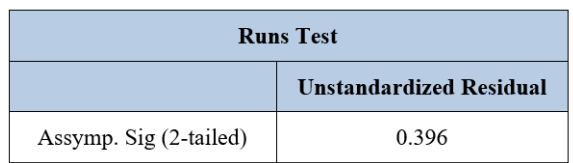

(Sumber: Data sekunder diolah)

Berdasarkan tabel 4.5 diatas, nilai sig sebesar $0.396>0,05$ artinya data terbebas dari autokorelasi yang berarti tidak terdapat korelasi antara error/residual nya. 


\section{Hasil Uji Hipotesis}

Analisis regresi linear berganda digunakan untuk mengetahui bagaimana variabel dependen dapat diprediksikan melalui variabel - variabel independen nya. Analisis regresi linear berganda dapat digunakan untuk memutuskan apakah ingin menaikkan atau menurunkan variabel independen dalam sebuah pengamatan. Menurut Sugiyono (2016) Untuk dapat menaikkan atau meningkatkan keadaan variabel dependen dapat dilakukan dengan meningkatkan variabel independen atau sebaliknya apabila ingin menurunkan keadaan variabel dependen dapat dilakukan dengan menurunkan variabel independen. Untuk mengetahui pengaruh antar variabel dependen dan independen dalam penelitian ini, peneliti menggunakan analisis regresi linier berganda dimana terdapat dua varibel Independen yang digunakan yaitu Corporate Risk dan Cost Shifting sedangkan variabel dependen yang digunakan yaitu Tax Avoidance.

Tabel 8 Hasil Uji Hipotesis

\begin{tabular}{|c|c|c|c|c|c|}
\begin{tabular}{c|c|c|c|} 
Variabel \\
Independen
\end{tabular} & $\begin{array}{c}\text { Unstandardized } \\
\text { Coefficient B }\end{array}$ & $\begin{array}{c}\text { Sig. } \\
\text { Coefficients }\end{array}$ & $\begin{array}{c}\text { Sig. } \\
\text { Anova }\end{array}$ & $\begin{array}{c}\text { Adjusted } \mathrm{R} \\
\text { Square }\end{array}$ & $\begin{array}{c}\mathrm{R} \\
\text { Square }\end{array}$ \\
\cline { 1 - 3 } Constant & 0.239 & 0.000 & & & \\
${$\cline { 1 - 3 }$} }$ & 0.016 & 0.005 & \multirow{2}{*}{0.0095} & 0.20 & 0.0265 \\
\cline { 1 - 3 } Cost Shifting & 0.012 & 0.032 & & & 0.0067 \\
\hline
\end{tabular}

Berdasarkan hasil pengujian dari tabel 4.6 diatas hasil pengujian hipotesis regresi linear berganda dapat disimpulkan sebagai berikut: Hasil Uji Hipotesis 1: Pengaruh Corporate Risk terhadap Tax Avoidance

Berdasarkan tabel 4.6 diatas dapat dilihat bahwa nilai Sig. variabel independen Corporate Risk adalah 0.005 menunjukkan bahwa nilai sig. $<\alpha(0.05)$ yang dapat diartikan bahwa terdapat pengaruh Corporate Risk terhadap Tax Avoidance secara parsial sebesar 0.0265 atau $2.65 \%$. Hasil tersebut memberikan bukti bahwa perusahaan dengan risiko yang tinggi akan mendorong manajemen untuk menghemat kasnya dalam kaitan pembayaran pajak
(Dhaliwal, Lee, Pincus dan Steele (2015) Dyreng, Hanlon dan Maydew (2008).

Perusahaan yang sedang menghadapi risiko (seperti kegagalan pembayaran pokok dan bunga atas hutang jangka panjang) akan lebih cenderung melakukan tax avoidance dibandingkan dengan perusahaan yang tidak terdapat masalah atas hutang jangka panjangnya. Perusahaan yang sedang menghadapi risiko kegagalan pembayaran pokok dan bunga atas hutang jangka panjangnya akan cenderung menghemat kasnya (termasuk melakukan tax avoidance) dalam rangka memenuhi kecukupan kasnya untuk dapat membayar pokok dan bunga atas kewajiban jangka panjangnya.

Jika perusahaan mampu untuk menghemat kasnya, maka manajemen akan dapat lebih leluasa untuk menggunakan kasnya untuk ekspansi perusahaan dan hal inilah yang mendorong manajemen melakukan penghindaran pajak. Kas yang tersedia dari hasil penghematan pajak akan dapat memungkinkan manajer mendapatkan bonus dan hal ini sesuai dengan teori agensi.

\section{Hasil Uji Hipotesis 2 : Pengaruh Cost Shifting terhadap Tax Avoidance}

Berdasarkan tabel 4.6 diatas dapat dilihat bahwa nilai Sig. variabel independen Cost Shifting adalah 0.032 menunjukkan bahwa nilai sig. $<\alpha(0.05)$ yang dapat diartikan bahwa terdapat pengaruh Cost Shifting terhadap Tax Avoidance secara parsial sebesar 0.0067 atau $0.67 \%$. Hasil tersebut mengindikasikan bahwa pilihan strategic cost shifting yang tepat akan mampu meminimalkan pajak yang akan dibayarkan ke Negara.

Hal tersebut sejalan dengan penelitian yang dilakukan oleh Hall dan Lusch (2018) melakukan penelitian mengenai strategic cost shifting and state tax minimation yang mana mereka menemukan bahwa perusahaan induk perbankan dinegara yang berbeda dengan anak perusahaan secara strategis mengalokasikan biaya 
diantara anak perusahaan perbankannya untuk meminimalkan pembayaran pajak.

Hasil penelitian ini memberikan bukti bahwa strategi peningkatan biaya yang dilakukan oleh manajemen akan mampu menghemat kas perusahaan dalam melakukan kewajiban pembayaran pajak serta manajer akan mendapatkan bonus dari hasil upaya nya untuk melakukan penghematan pajak perusahaan, hal ini sesuai dengan agensi teori.

\section{Simpulan dan Saran}

\section{Simpulan}

Penelitian ini bertujuan untuk mengetahui pengaruh Corporate Risk dan Cost Shifting terhadap Tax Avoidance. Berdasarkan pengujian yang telah dilakukan, hasil penelitian ini menjelaskan bahwa:

a. Terdapat pengaruh positif Corporate Risk terhadap Tax Avoidance secara parsial. Yang berarti bahwa perusahaan yang sedang menghadapi risiko (seperti kegagalan pembayaran pokok dan bunga atas hutang jangka panjang) akan lebih cenderung melakukan tax avoidance dibandingkan dengan perusahaan yang tidak terdapat masalah atas hutang jangka panjangnya.

b. Terdapat pengaruh positif Cost Shifting terhadap Tax Avoidance secara parsial. Yang berarti bahwa perusahaan secara strategis mengalokasikan biaya yang ada didalam perusahaan untuk meminimalkan pembayaran pajak.

\section{Saran}

Hasil penelitian ini dapat menjadi masukan bagi regulator pajak dalam membuat kebijakan dan peraturan perpajakan yang dapat mencegah perilaku tax avoidance yang mengarah kepada tax aggressiveness. Sedangkan keterbatasan dari penelitian ini adalah dari segi objek penelitian yang mana penelitian ini berfokus hanya pada perusahaan manufaktur dan bukan pada seluruh perusahaan yang terdaftar di Bursa Efek Indonesia.

Keterbatasan penelitian ini juga tidak memasukkan risiko liabilitas perusahaan serta tidak memasukkan rasio kecukupan modal bagi perusahaan perbankan sehingga penelitian selanjutnya dapat menggunakan risiko liabilitas perusahaan dan rasio kecukupan modal untuk mengetahui faktor penentu penghindaran pajak. Peluang riset selanjutnya dapat menggunakan variabel risiko liabilitas dan rasio kecukupan modal bagi perusahaan perbankan serta memasukkan semua sektor perusahaan yang terdaftar di Bursa Efek Indonesia untuk penelitian selanjutnya.

\section{Daftar Pustaka}

Beatty, A., S. L. Chamberlain, and J. Magliolo. 1995. Managing Financial Reports of Commercial Banks: The Influence of Taxes, Regulatory Capital, and Earnings. Journal of Accounting Research 33 (2): 231-261. doi: $10.2307 / 2491487$

Boivie, S., Christensen, D., Dhaliwal, D., Graffin, Scott, D. 2012. Managers' personal political orientation and corporate tax avoidance. Working paper. University of Arizona.

Brown, J., K. Drake and M. Martin. 2016. Compensation in the Post-FIN 48 Period: The Case of Contracting on Tax Performance and Uncertainty. Contemporary Accounting Research, Vol.33, No.1.

Dhaliwal, S. Dan, H. S. G. Lee, M. Pincus, L. B. Steele. 2017. Taxable Income. The Journal of the American Taxation Association Vol. 39 No. 1: 1-24.

Dyreng, S., M. Hanlon, and E. Maydew. 2008. Long Run Corporate Tax Avoidance. The Accounting Review 83: 61-82.

Dyreng, S., M. Hanlon, and E. Maydew. 2014. Rolling the Dice: When Does Tax Avoidance Results in Tax Uncertainty? 
Working Paper, Duke University, Massachusetts Institute of Technology, and The University of North Carolina.

Dyreng, S.D., M. Hanlon, \& E. L. Maydew. 2010. The Effects of Executives on Corporate Tax Avoidance. The Accounting Review, Vol 85 (No. 4): 1163-1189.

Eisenhardt, Kathleem.(1989). Agency Theory: An Assesment and Review. Academy of Management Review, 14.Hal 57-74.

Finnerty, C., P. Merks, M. Petriccione, R. Russo. 2007. Fundamentals of International Tax Planning. IBFD. ISBN:978-90-8722-016-7.

Ghozali, Imam. 2011. Aplikasi Analisis Multivariate Dengan Program IBM SPSS 19 (edisi kelima.).Semarang: Universitas Diponegoro.

Guenther, D. A., S. R. Matsunaga, B. M. Williams. 2017. Is Tax Avoidance Related to Firm Risk?. The Accounting Review, Vol.92 (No.1): 115-136.

Hall, M. C., and L. J. Stephen. 2018. Strategic Cost Shifting and Tax Minimization. Journal of Management Accounting Research, Vol. 30 (No.1): 55-72.

Hanlon, M., S. Laplante, and T. Shevlin. 2005. Evidence on the information loss of conforming book income and taxable income. Journal of Law and Economics 48: 407-442.

Higgins, D., T. Omer and J. Phillips. 2012. Tax Avoidance versus Aggressiveness: The Influence of a firm's business strategy. Working Paper, University of Connecticut.

Khotari C.H. 2004. Research Methodology methods and techniques. http://www.modares.ac.ir/uploads/Agr. Oth.Lib.17.pdf.

Langenmayr, D., and R. Lester. 2018. Taxation and Corporate Risk-Taking. The Accounting Review, Vol. 93 (No.3), Hal 237-266.

Ljungqvist, A., L. Zhang, L. Zuo. 2017. Sharing Risk with Government: How
Taxes Affect Corporate Risk Taking. Journal of Accounting Research, Vol.55 (No.3). Available at SSRN: https://ssrn.com/abstract $=3054753$

McGuire, S., D. Wang, and R. Wilson. 2011. Dual Class Ownership and Tax Avoidance, American Taxation Association Midyear Meeting: Jata Conference.

McGuire, S. T., S. Neuman, and T. Omer. 2013. Sustainable Tax Strategies and Earnings Persistence. Working paper, Texas A\&M University and University of Nebraska-Lincoln.

Rego, S., and R. Wilson. 2012. Equity Risk Incentives and Corporate Tax Aggressiveness. Journal of Accounting Research 50: 775-809.

Robinson, J., Y. Xue, and M. Zhang. 2012. Tax Planning and Financial Expertise in the Audit Committee. Working Paper.

Subramanyam, K.R dan Wild, John. 2013. Analisis Laporan Keuangan. Buku 1. Edisi Kesepuluh (Terjemahan). Jakarta: Penerbit Salemba Empat.

Sugiyono. 2016. Metode Penelitian Kuantitatif Kualitatif dan $R \& B$. Bandung: Alfabeta.

Sugiyono. 2013. Metode Penelitian Pendidikan Pendekatan Kuantitatif, Kualitatif, dan $R \& D$. Bandung: Alfabeta.

Scholes, M. S., G. P. Wilson, and M.A. Wolfson. 1990. Tax Planning, Regulatory Capital Planning, and Financial Reporting Strategy for Commercial Banks. Review of Financial Studies 3 (4): 625-650. doi: 10.1093/rfs/3.4.625.

Scott, William R., (2003), Financial Accounting Theory, 3rd edition, Prentice Hall, United States of America. 